Aug-18-98 12:44pm From-APT/TPD

Approved lor puble release; distributon is unimited.

Los Alamos National Laboratory, an affirnative actionvequal opporitring employer, is operated by the Universiny of Calitorna br the US. Department of Energy under contract W-7405-ENG-36. By acceptance of this article, the puplisher recognizes that the $U$ S. Government retains a nonexclusive, royalty-trese license ro puplish or reproduce the published form of this contributon, or to allow others to do so, for u.S Govemment purposes. Los Alamos Narional Laboratory requests that the puplisher identify thes article as work pertormed uncer the auspices of the U.S. Department of Energy. Los Alamos National Laporajory strongly supports academic freedom and a researcher's nght to publish, as an instipution, however, the Laboratory does not endorse the viewpoint of a publication or guarantee its technical correciness. 


\section{DISCLAIMER}

This report was prepared as an account of work sponsored by an agency of the United States Goverament. Neither the United States Government nor any agency thereof, nor any of their employees, makes any warranty, express or implied, or assumes any legal liability or responsibility for the accuracy, completeness, or usefulness of any information, apparatus, product, or process disclosed, or represents that its use would not infringe privately owned rights. Reference herein to any specific commercial product, process, or service by trade name, trademark, manufacturer, or otherwise does not necessarily constitute or imply its endorsement, recommendation, or favoring by the United States Government or any agency thereof. The views and opinions of authors expressed herein do not necessarily state or reflect those of the United States Government or any agency thereof. 


\section{DISCLAIMER}

Portions of this document may be illegible in electronic image products. Images are produced from the best available original document. 


\title{
ADVANCED BUCK CONVERTER POWER SUPPLY "ABCPS" FOR APT *
}

\author{
R. Street, T. Overetr, E. Bowles \\ Gencral Atornics, San Diego, California 92186-5608 USA
}

\begin{abstract}
Abstracl
The United States Deparment of Energy (DOE) is planning to fabricale an Accelerator for the Production of Tritiun (APT) at their Savannah River Site, to provide Tritium for national defense. The 1700 million electron volr (MeV) protan beam accelerator will be powered by radio frequency (RF) klystrons. A direct current (DC) power supply is required for each of the approximately two hundred and fifty lmegawan (MW) continuous wave klystrons in the RF power system. The requirements are that the power supply ineet output performance specifications, provide fault prorection for the klystron, have high efficiency, high reliabulity, good maintainability, and be readily manufacturable As the power supplies are one of the largest cost elements in the accelerator, a technology review was made to determine the most economical approach to sarisfy the requirements. A switch-mode power supply employing a buck-regulator was identified as being potantially the lowest cost approach. As the switch represents \& certain development risk, a small-scale prototype has been constructed for evaluarion, and his resulted in the decision to fabricate a full-scale prototype power supply. A descriprion of the hardware will be presented.
\end{abstract}

\section{Introduction}

The proposed APT plant will use proven accelerator based technology. The $1700 \mathrm{MeV}$ proton accelerator will utilize three standard 350 megahenz $(\mathrm{MHz})$ klystron RF sources to drive the RF Quadrupole. There will be two hundred and forty one $700 \mathrm{MHz}$ klystron RF sources to power the norma! temperature lowenergy linac and the super-conducting radio frequency cavities in the high energy linuc to create the highenargy Proton beam.

\section{APT RF Power System}

The APT plant requires one high vultage power supply (HVPS) for each of the 244-klystron RF power sources. Three HVPS provide $2 \mathrm{MW}$ DC to $1.2 \mathrm{MW}$ (RF) klystrons and the fost of the supplies $16 \mathrm{MW} D C$ to I $\mathrm{MW}$ (RF) klystrons. $2 \mathrm{MW} \mathrm{DC}$ power supplies rated for negative 95 Kilovolts $(k V)$ (Q) 21 Amperes
(A) DC are planned throughour for cornmonality. The requiremonts art that the HVPS met outpur pertormance specifications, provide fauli protaction for the klystron, have high efficiency, high reliability, good maintainability, and be readily manufacturable. As the HVPS are one of the largest cost elements in the accelerator, a trchnology review was made to determine the most economical approach to santsfy the requirements. The results of that review indicated a switch-mode power supply employing a buck-regulator was potentrally the lowest cost approach to satisfy all plant requirements.

The buck-regulator ropology is potentially the most economical because the high voltage rectifier bridge and the high voltage step-up rectifier transformet are removed from the power supply. All other topologies, including the resonant power supply utilize expensive magnetic components, which increase their costs and complicate their manutacturability.

To accomplish this, the $230-k V$ high voltagk, urility distribution rransformers become the rectifier transformars. The transformer secondary voltage is rectified to provide twelve pulse DC power to the system. This also simplities and reduces the cost of the utility distribution system for APT because the usual branch circuits and components used to stepdown the urility voltage to a workable medium voltage are not required.

The urility source $230-k V, 677$ megavoli-ampere (MVA) line feeds four substanons. Each of four substacions (Fig. 1) will contain two, 60 MVA isolation transformers for a total substation capucity of 120 MVA. This allows each substation to feed twenry five percent of the HVPSs. For redundancy, two high voltage rectifie bridges will be connected to the secondary of cach distriburion transformer. There will be a lotal of eight tectifier-transformers and sixteen rectifier bridges. Interphase transformers will tie the rectifier outpuss from the phase-shifted transformets to make twelve pulse ripple. The transformer secandary is eighty-iwo $\mathrm{kV}$ ims. It is then rectified to $115 \mathrm{kV}$ DC. Each rectifler bridge will be sized to suppon twice the usual number of HVPSs, in case one rectifier is out of service. Each of the fow DC transmission grids will feed a minimum of sixty-one power supplies. Only three HVPSs will actually operare at 21 A. The

\footnotetext{
- Work supported by DOE under contract: DE-AC04-96AL 89007
} 
remaining HVPSs will operate at $17 \mathrm{~A}$. Fig- 1 shows a typical distribution substation pair of recrifier the RF power system rransformers including the $D C$ recuffiers dedicared to

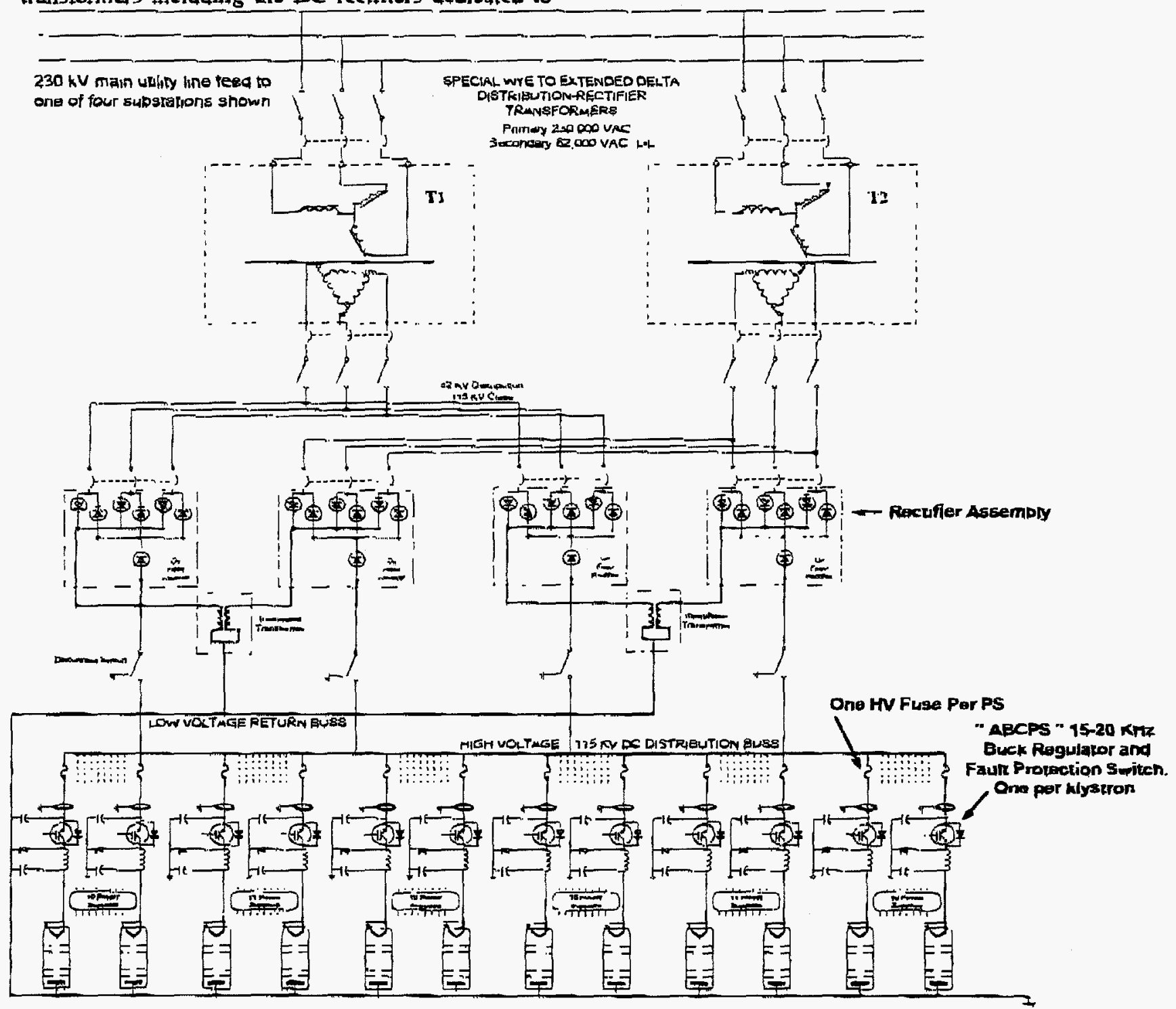

Figure 1: "ABCPS" DC Distribution System for APT

\section{ABCPS}

The Advance Buck Converter Power Supply, (ABCPS) is connected directly to the DC distrubution buss. The topology of this converter is a $D C$ to $D C$ buck chopper and will regulate the applied volrage to one klysiron. A citcuit schematic of a single ABCPS is shown in Fig. 2, The raw HVDC input is switched at approximately 20 kilohertz by a HV IGBT switch and charges the output capacitor through a switching inductor. A freewheeling diode transfers the inductor energy into the outpur capacitor during the IGBT switch off time. The circuit operates in the discontinuous current mode.

Addinonal outpur filter sections reduce output ripple volrage and also provide instantaneous tault energy limiting to the klystron. During operation, when the klystron may ure internally, the IGBT switch will interrupt the high voliage powtr supply output current in one mictosecond or less. To prevent damage to the klystron, less than 40 joules will be deposited during an internal plasma arc Individual primary high voltage fast acting fuses will be used for back-up power supply and klystron load protection. 
The high voltage JGBT switch ussembly is designed for ease of maintenance. The IGBTs, heat sinks, and gate drive circuits are mounted on plug-in circuit cards. Fiber optuc signal isolation is utulized throughout the HVPS. The entire switch assembly can be bench manufactured and does not require special manufacruring or heavy assembly zquipment. In addition no large magnetic cores are needed. All the HVPS inductors are single layer wound air-core colls. The majority of the HVPS components are slandard off the shelf types. This manufaeturng approach reduces cost and procurement lead-time.

The most critical cireuitry in this ABCPS is the high voltage soldd-state switch. This switch is a string of puired IGBTs connected in series to hold off the 115-kV DC inpur. References [1] through [6]. The IGBTs are paired to provide redundancy. Uniform volkage sharing across zach device is crirical under all operating conditnons. Each IGBT will have an independent gate control circuir. Once the fault is detacted, the IGBT switch can operate in less than one microsecond to protecr the klystron and provide fast voltage regularion and control.

\section{HVPS Output Characteristics}

Ourput DC volrage: Continuously variable- 4 to -95 kV

Outpur DC polarity: Negative with respect to ground

Output voltage set-point yccuracy: $T /$ - 400V

Ourfur voltage rate of increase- $10 \mathrm{kV} /$ second max. Output current rate of increase: $200 \mathrm{~A}$ / second max.

Figure 2: ABCPS Schematic
Rrgulation range: $10-95 \mathrm{kV}$

Regulation reguirements (line \& load); $T /-400 \mathrm{~V}$ max. Ripple (e) any $60 \mathrm{~Hz}$ harmonic: $800 \mathrm{~V}$ pk to pk max. Total ripple (all causes): $1100 \mathrm{~V}$ peak to peak max

Voltage stability $+1-04 \%$ max.

Output DC current: 0 - 21 A

Load fault protection 40 Joules max.

\section{REFERENCES}

[1] V.Chutra, S. Hong, and David A. Torrey, "Series Connection of IGBTs with Active Voltage Balancing", IEEE 1997

[2] P.R Palmer and A.N Githiar, "The Series Connection of IGBTs with Active Voliuge Sharing", IEEE PESC 1997, Pp 637-644

[3] C.Gesier, $P$ Hofer, N Karrer, "Gate-control Strategy for Snubberless Operation of Series Connected IGBTs", PESC 1996, pp.1739-1742

[4] P.R. Palmer and A.N. Githiari, "The Series Connection of IGBTs with Opumnized Voltage Sharng in the Switching Transient" Procecdings of IEEE PESC 1995, Vol. 1, pp.44-49.

[5] C Gester, "Fast High Power/High Voltage Switch Using Series Connected IGBTs with Active GateControlled Voltage Balancing", APEC 1994, PP.469-472.

[6] M. Tsuneoka, M. Takouchi, and 1. Takahash, "The Design of RF Power Supply using DC-DC Converter", IEEE 1989, PP. 1206-1209.
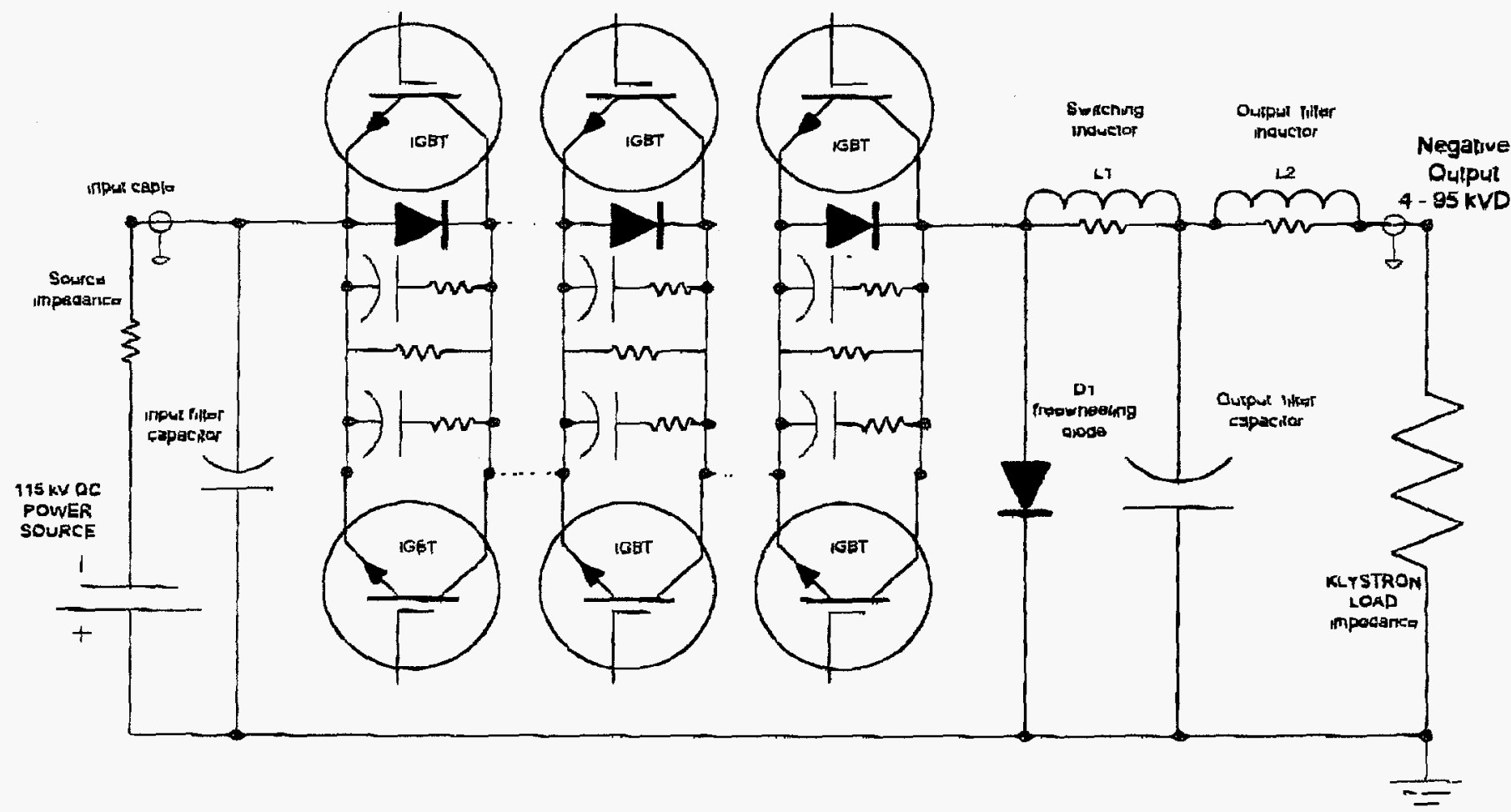